\title{
Article \\ Effects of Actual Marine Atmospheric Pre-Corrosion and Pre-Fatigue on the Fatigue Property of 7085 Aluminum Alloy
}

\author{
Laixin Shi ${ }^{1, *}$, Lin Xiang ${ }^{2, *}$, Jianquan Tao ${ }^{2}$, Jun Liu ${ }^{2}$, Qiang Chen ${ }^{2}$ and Yong Zhong ${ }^{2}$ \\ 1 College of Material Science and Engineering, Chongqing University of Technology, Chongqing 400054, China \\ 2 Precision Forming Center, Southwest Technology and Engineering Research Institute, \\ Chongqing 400039, China; jarryallen@163.com (J.T.); bvvh_liu@163.com (J.L.); \\ 2009chenqiang@hfut.edu.cn (Q.C.); wanshi3816@163.com (Y.Z.) \\ * Correspondence: shilaixin2016@cqut.edu.cn (L.S.); xlin0731@163.com (L.X.); Tel.: +86-15123376156 (L.S.); \\ +86-18792897339 (L.X.)
}

check for

updates

Citation: Shi, L.; Xiang, L.; Tao, J.; Liu, J.; Chen, Q.; Zhong, Y. Effects of Actual Marine Atmospheric

Pre-Corrosion and Pre-Fatigue on the Fatigue Property of 7085 Aluminum Alloy. Metals 2022, 12,81. https:// doi.org/10.3390/met12010081

Academic Editors: Sebastian feliu batlle and Chonghe Li

Received: 4 December 2021 Accepted: 30 December 2021 Published: 4 January 2022

Publisher's Note: MDPI stays neutral with regard to jurisdictional claims in published maps and institutional affiliations.

Copyright: (C) 2022 by the authors. Licensee MDPI, Basel, Switzerland. This article is an open access article distributed under the terms and conditions of the Creative Commons Attribution (CC BY) license (https:// creativecommons.org/licenses/by/ $4.0 /)$.

\begin{abstract}
Effects of actual marine atmospheric precorrosion and prefatigue on the fatigue property of 7085-T7452 aluminum alloy were investigated by using the methods of marine atmospheric outdoor exposure tests and constant amplitude axial fatigue tests. Marine atmospheric corrosion morphologies, fatigue life, and fatigue fractography were analyzed. After three months of outdoor exposure, both pitting corrosion and intergranular corrosion (IGC) occurred, while the latter was the dominant marine atmospheric corrosion mode. Marine atmospheric precorrosion could result in a dramatical decrease in the fatigue life of the as-received 7085-T7452 aluminum alloy, while selective prefatigue can improve the total fatigue life of the precorroded specimen. The mechanism of the actual marine atmospheric corrosion and its effects on the fatigue life of the 7085-T7452 aluminum alloy were also discussed.
\end{abstract}

Keywords: 7085 aluminum alloy; actual marine atmospheric environment; outdoor exposure test; corrosion; fatigue

\section{Introduction}

7085 aluminum alloy has received great attention in aerospace and automotive industries because of its outstanding properties such as low density, high specific strength, low quenching sensitivity, and good thermal stability [1-9]. Recently, 7085 aluminum alloy has been used as structural parts in aircrafts, which are usually subjected to fatigue loading damage $[10,11]$. Thus, a comprehensive understanding of the fatigue property of 7085 aluminum alloy is necessary. Several studies have been performed to elucidate the fatigue behavior of 7085 aluminum alloy [12-16]. Burns et al. [12] investigated the role of the plate thickness on the fatigue crack growth behavior of 7085 aluminum alloy and found that the increased crack path roughness, tortuosity, and branching in the thicker plate might result from the strain localization/cracking along precipitate-free zones. Dai et al. [14] studied the fracture characteristics of a 7085 aluminum alloy thick plate during high-cycle fatigue and pointed out that the fatigue crack of the 7085 aluminum alloy thick plate mainly initiates at the locations of coarse Fe-rich particles on the specimen surface. Luong et al. [16] studied the high-cycle fatigue performance of 7085 aluminum alloy treated with combinations of laser peening and anodisation processes and reported that laser peening could significantly improve the fatigue property of 7085 aluminum alloy.

In addition, as aircrafts are in service in coastal regions, the damage process of aircraft aluminum alloy structures is mainly in the alternate "corrosion + fatigue" mode, i.e., marine atmospheric corrosion damage is dominant when the aircraft parks in the airport, while the fatigue loading damage is dominant when the aircraft is flying in a high-altitude environment [17]. Obviously, marine atmospheric precorrosion and prefatigue loading should have significant influences on the fatigue life of aluminum alloys. The effects 
of the precorrosion on the fatigue properties of aluminum alloys have been extensively investigated [18-23]. For example, Song et al. [18] studied the fatigue damage evolution in a precorroded 7075-T7651 aluminum alloy and found that the precorrosion of $48 \mathrm{~h}$ in a standard exfoliation corrosion (EXCO) solution $\left(234 \mathrm{~g} / \mathrm{L} \mathrm{NaCl}, 50 \mathrm{~g} / \mathrm{L} \mathrm{KNO}_{3}\right.$ and $6.3 \mathrm{~mL} / \mathrm{L} \mathrm{HNO}_{3}$ ) leads to a considerable decrease in the fatigue life. Genel [20] investigated the effect of the pitting on the bending fatigue performance of the 7075-T6 aluminum alloy precorroded by immersion in a $3.5 \% \mathrm{NaCl}$ solution and reported that the decrease in fatigue strength could reach about $60 \%$ owing to the presence of pitting. Walde et al. [22] studied multiple fatigue crack growth behaviors of a precorroded 2024-T3 aluminum alloy by accelerated corrosion and developed a fracture mechanics-based model to simulate the multiple crack growth process.

However, to our knowledge, no study has been concerned on the effects of actual marine atmospheric precorrosion and "precorrosion + prefatigue" on the fatigue property of 7085 aluminum alloy so far. In this paper, actual marine atmospheric outdoor exposure tests of 7085-T7452 aluminium alloy were performed for three months to obtain marine atmospheric precorroded specimens. Atmospheric precorrosion + fatigue (PCF) tests and precorrosion + prefatigue + fatigue (PCPFF) tests were carried out to obtain the fatigue life of aluminum alloy specimens. The characteristics of the surface corrosion and the fatigue fractography were analyzed. The mechanism of actual marine atmospheric corrosion and its effects on the fatigue life were also discussed.

\section{Experimental Procedure}

The materials used in this work were 7085-T7452 aluminium alloy forgings supplied by Southwest Aluminum (Group) Co., Ltd., Chongqing, China. The chemical compositions (wt \%) of the 7085-T7452 aluminium alloy are shown in Table 1. In addition, the average yield strength and tensile strength of the 7085-T7452 aluminium alloy were about $468 \mathrm{MPa}$ and $516 \mathrm{MPa}$, respectively. Dog-bone-shaped fatigue specimens (about $3 \mathrm{~mm}$ in thickness and $80 \mathrm{~mm}$ in radius of the middle arcs (R80)), as indicated in Figure 1, were cut from the 7085-T7452 aluminium alloy forgings for marine atmosphere outdoor exposure tests and fatigue tests. The surfaces of the as-received 7085-T7452 aluminium alloy specimens were smooth and uncorroded (see Figure 1b).

Table 1. Chemical compositions (wt \%) of the 7085-T7452 aluminum alloy.

\begin{tabular}{cccccccccc}
\hline Element & Zn & Mg & Cu & Fe & Ti & Si & Cr & Mn & Al \\
\hline Composition (wt \%) & 7.02 & 1.35 & 1.54 & 0.054 & 0.024 & $<0.05$ & $<0.02$ & $<0.02$ & Bal. \\
\hline
\end{tabular}

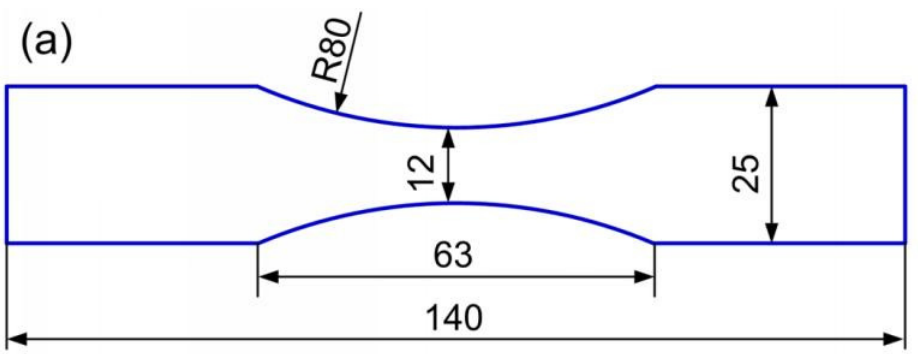

(b)

Unit: $\mathrm{mm}$

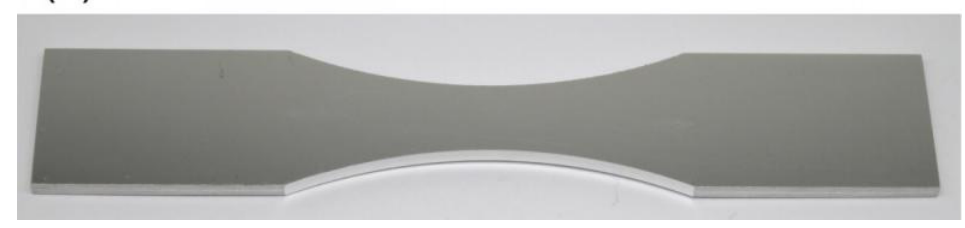

Figure 1. (a) Geometry and dimensions of the specimens; (b) surface morphology of the as-received 7085-T7452 aluminium alloy specimen. 
The tests of the outdoor exposure in actual marine atmosphere were performed at the Wanning test site located at north latitude $18^{\circ} 58^{\prime} 05^{\prime \prime}$ and east longitude $110^{\circ} 30^{\prime} 31^{\prime \prime}$ in Hainan, China. Aluminum alloy specimens were installed on a test rack with the southfacing surface, at an inclination of $45^{\circ}$ from the horizontal surface. The test rack was $350 \mathrm{~m}$ away from the coast. The specimens were directly subjected to the comprehensive effects of solar radiation, rain, salt spray, temperature, and humidity. Precorroded specimens exposed to the marine atmospheric environment for three months were retrieved and kept in a desiccator (DZF-6020, Hefei Kejing Materials Technology Co., Ltd., Hefei, China). The surface morphologies of the specimens suffering from atmospheric precorrosion were observed using a scanning electron microscope (Evo18, Carl Zeiss, Oberkochen, Germany). The selected specimens were cross-sectioned and polished for microstructural observation by using an optical microscope (OM DMI5000M, Leica, Wetzlar, Germany). Thin foils of the selected specimens were prepared for microstructural analysis by a transmission electron microscope (JEM-2100, JEOL Ltd., Tokyo, Japan).

The constant amplitude axial fatigue tests of the uncorroded (as-received) and precorroded specimens were carried out using a QBG-50 fatigue-testing machine (Changchun Qianbang, Changchun, China) in laboratory air at room temperature. For the uncorroded fatigue (UCF) and PCF tests, the specimens were under cyclic loading until fracture, and then the total fatigue life $\left(N_{\mathrm{f}}\right)$ was obtained. For the PCPFF tests, the selected precorroded specimens were firstly preloaded for $10^{4}$ cycles $\left(N_{\mathrm{pf}}\right)$, then unloaded, held for about 3 min and finally reloaded until fracture to obtain the residue fatigue life $\left(N_{\mathrm{rf}}\right)$. That is, for the PCPFF aluminum alloy specimens, the total fatigue life $N_{\mathrm{f}}$ was the sum of $N_{\mathrm{pf}}$ and $N_{\mathrm{rf}}$, and the prefatigue life $\left(N_{\mathrm{pf}}\right)$ was $10^{4}$ cycles. Sine a wave load and the maximum cyclic stress of $230 \mathrm{MPa}$ were applied in all the fatigue and prefatigue tests. Moreover, the stress ratio (R) was set as 0.1 , and the loading frequency was about $80 \mathrm{~Hz}$. All the fatigue tests were repeated at least five times. The micromorphology characteristics of fatigue fractures were analyzed by a scanning electron microscope (Evo18, Carl Zeiss, Oberkochen, Germany).

\section{Results and Discussion}

\subsection{Corrosion Characteristics}

Figure 2 shows the surface morphology of the 7085-T7452 aluminum alloy specimen exposed to an actual marine atmosphere for three months. As indicated, the aluminum alloy specimen suffered from serious corrosion. Pitting corrosion could be observed at the local region of the specimen surface, and some surface corrosion products were cracked.
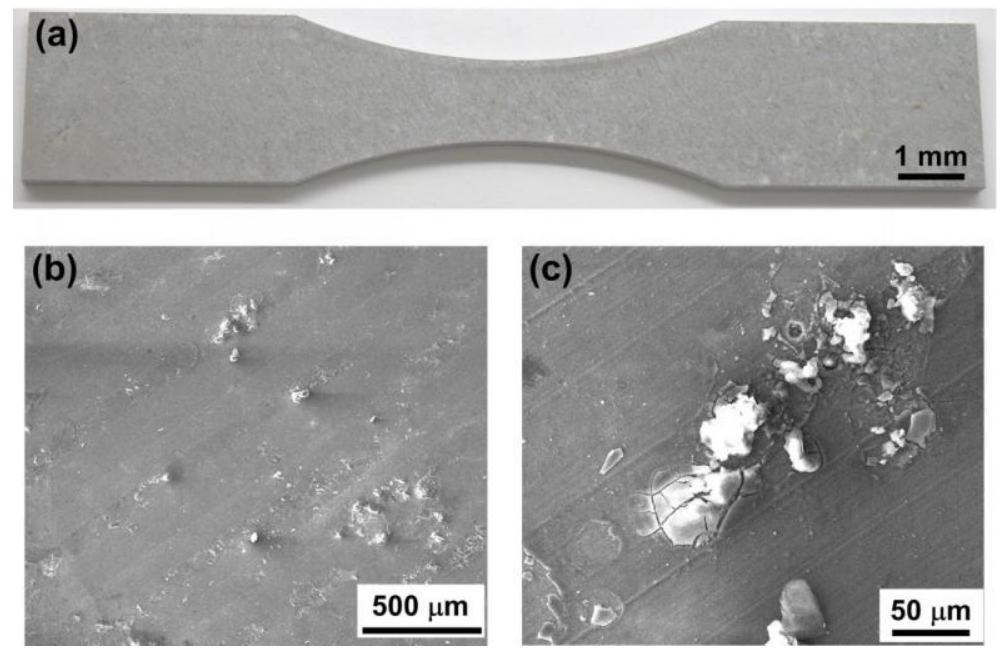

Figure 2. Surface morphologies of the 7085-T7452 aluminum alloy specimen exposed to an actual marine atmosphere for three months: (a) at a macroscopic scale; and $(\mathbf{b}, \mathbf{c})$ at a microscopic scale. 
Figure 3 shows the cross-sectional morphologies of different 7085-T7452 aluminum alloy specimens. It can be seen that no visible corrosion occurred in the as-received specimen (Figure 3a), which was consistent with the result of surface morphology (Figure 1). After three months of outdoor exposure in a marine atmosphere, pitting corrosion and intergranular corrosion (IGC) could be observed in the 7085-T7452 aluminum alloy, as indicated in Figure $3 \mathrm{~b}$. The maximum depth of the IGC zone was about $96.3 \mu \mathrm{m}$. It was suggested that the 7085-T7452 aluminium alloy was sensitive to IGC, which was the dominant corrosion damage mode. Furthermore, the morphology of the precorrosion + prefatigue aluminum alloy specimen (see Figure 3c) was similar to that of the precorroded specimen.

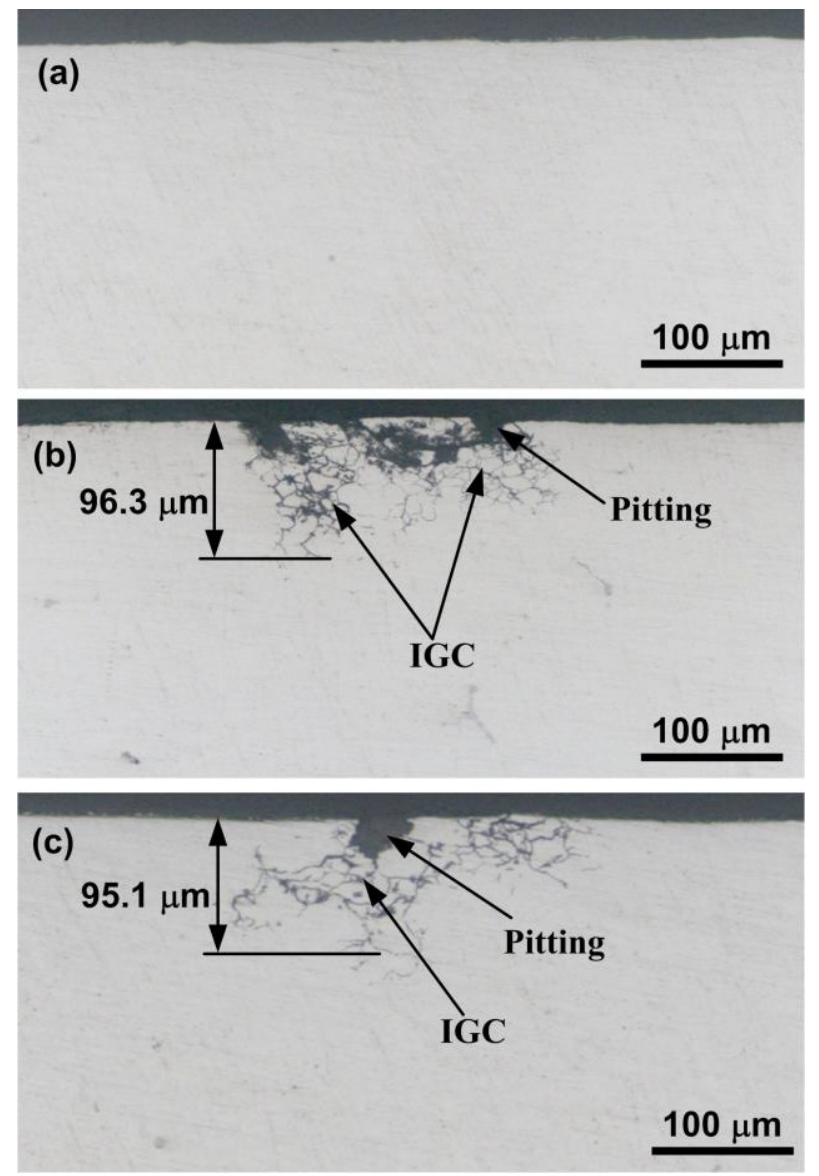

Figure 3. Cross-sectional morphologies of the 7085-T7452 aluminum alloy specimens: (a) as-received; (b) precorrosion; and (c) precorrosion + prefatigue.

The average air temperature, relative humidity and $\mathrm{Cl}^{-}$deposition rate at the Wanning test site were about $23.9^{\circ} \mathrm{C}, 87.6 \%$ and $14.5875 \mathrm{mg} /\left(\mathrm{m}^{2} \mathrm{~d}\right)$, respectively [24]. As indicated, the actual marine atmosphere environment at the Wanning test site was characterized by high temperature, high humidity and high salt fog. In this case, electrolyte water films containing $\mathrm{Cl}^{-}$easily formed on the 7085-T7452 aluminum alloy surface. $\mathrm{Cl}^{-}$in the water films could preferentially destroy the local and weak area of the surface oxide film of the aluminum alloy and thus resulted in pitting holes progressively. Under the action of an electrolyte solution, corrosive galvanic cells might be formed by the aluminum alloy matrix exposed in pitting holes and the adjacent surface oxide film. The 7085-T7452 aluminum alloy matrix had a lower corrosion potential and acted as the anode. The surface oxide film of the aluminium alloy had a higher corrosion potential and acted as the cathode. The small anode and the large cathode formed in the pitting holes could accelerate the corrosion dissolution of the 7085-T7452 aluminum alloy matrix. 
As pitting corrosion reached a certain degree, the corrosion began to develop along the grain boundary to the interior of the 7085-T7452 aluminum alloy matrix and thus IGC occurred. It is known that the IGC is closely related to the microstructure of aluminum alloy. Generally, the precipitation sequence of the second phase in 7xxx alloy system during the aging process could be expressed as [25-27]:

Supersaturate solid solution $\rightarrow$ Guinier-Preston $(\mathrm{GP})$ zones $\rightarrow \eta^{\prime} \rightarrow \eta\left(\mathrm{MgZn}_{2}\right)$.

where GP zones are the enrichment regions of $\mathrm{Mg}$ and $\mathrm{Zn}$ atoms; $\eta^{\prime}$ is the transition phase; $\eta\left(\mathrm{MgZn}_{2}\right)$ is the equilibrium phase. GP zones and $\eta^{\prime}$ usually precipitate within the grains, while $\eta\left(\mathrm{MgZn}_{2}\right)$ is formed at the grain and/or sub-grain boundaries in 7xxx aluminum alloy [28]. As shown in Figure 4, for the used 7085-T7452 aluminum alloy, lots of fine precipitates exhibited a homogeneous distribution in the matrix grains, while some coarser precipitates were identified at the grain boundaries. These grain boundary precipitates (GBPs) could be deduced to be the equilibrium $\eta\left(\mathrm{MgZn}_{2}\right)$ phase [28-30], which was also confirmed by the electron diffraction pattern of the GBPs, as indicated in Figure 4c. Compared with the 7085-T7452 aluminum alloy matrix, the corrosion potential of $\eta\left(\mathrm{MgZn}_{2}\right)$ was lower [31] and would act as the anode. Consequently, under the action of electrolyte water films containing $\mathrm{Cl}^{-}$, the GBPs were preferentially dissolved, and thus, the grain boundaries suffered from corrosion, inducing the IGC. Furthermore, the pollutants such as $\mathrm{SO}_{2}$ and $\mathrm{NO}_{2}$ in the actual marine atmosphere could be dissolved in the electrolyte water film on the surface of the aluminum alloy and gave rise to corrosive ions $\left(\mathrm{SO}_{4}{ }^{2-}\right.$ and $\mathrm{NO}_{3}{ }^{-}$) [32], accelerating the marine atmospheric corrosion of the 7085-T7452 aluminum alloy specimens.
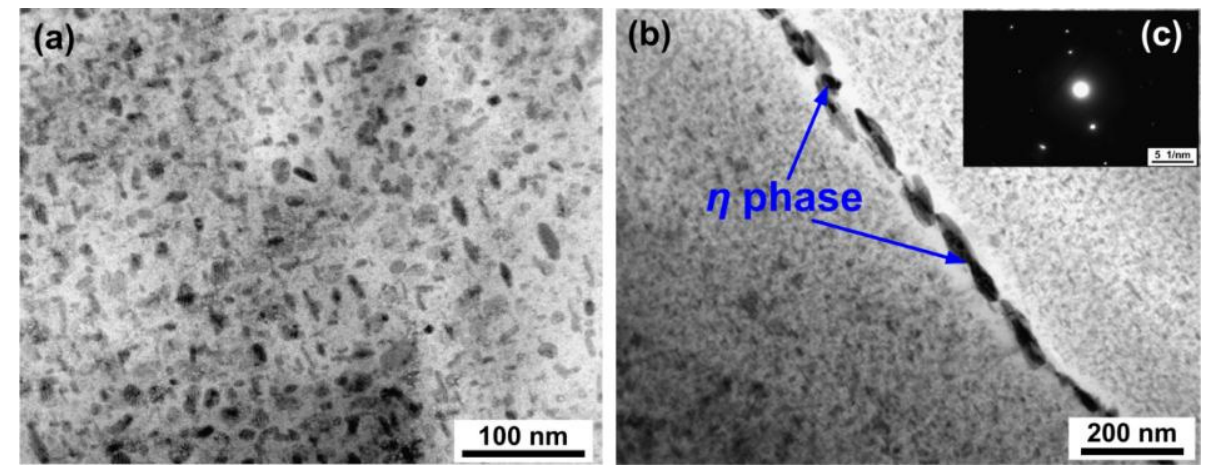

Figure 4. TEM images of the 7085-T7452 aluminum alloy specimen: (a) grain interior morphology; (b) grain boundary morphology; and (c) electron diffraction pattern of grain boundary precipitates (GBPs).

\subsection{Fatigue Property}

Figure 5 shows the average fatigue lives of different 7085-T7452 aluminum alloy specimens. As indicated, the average total fatigue lives $\left(N_{\mathrm{f}}\right)$ of the PCF and PCPFF aluminum alloy specimens exposed for three months were about $2.2 \times 10^{4}$ cycles and $3.1 \times 10^{4}$ cycles, respectively. They were much lower than that of the as-received (UCF) specimen (about $33.1 \times 10^{4}$ cycles). In addition, it should be noted that the average total fatigue life $\left(N_{\mathrm{f}}\right)$ of the PCPFF aluminum alloy specimens was increased by about $41 \%$ compared with that of the PCF specimens, suggesting that selective prefatigue could improve the fatigue life of the atmospheric-precorrosion 7085-T7452 aluminum alloy. 


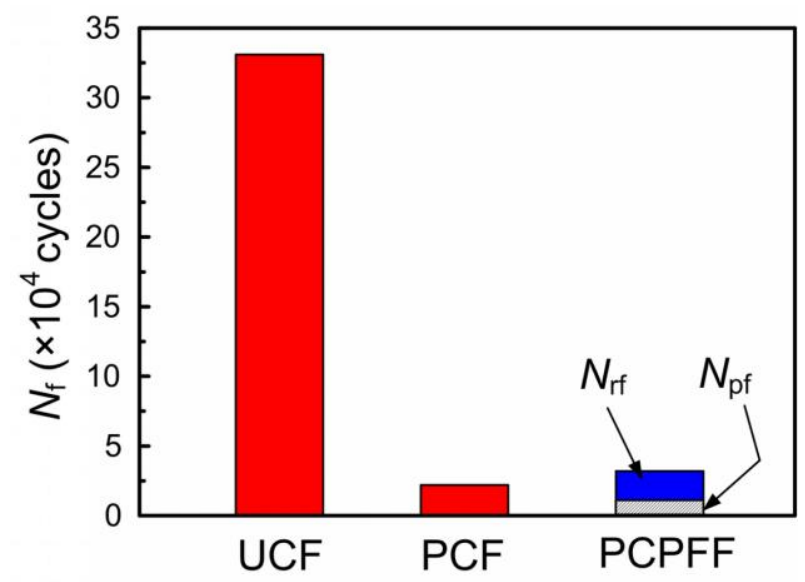

Figure 5. Average fatigue lives of different 7085-T7452 aluminum alloy specimens: $N_{\mathrm{f}}, N_{\mathrm{pf}}$, and $N_{\text {rf }}$ are the total fatigue life, prefatigue life, and residue fatigue life, respectively.

Figure 6 shows the SEM images of fatigue fractography of the UCF, PCF, and PCPFF 7085-T7452 aluminium alloy specimens. For the UCF (as-received) specimen, the initiation of fatigue crack occurred at the specimen surface defect, which was easier to induce stress concentration, as shown in Figure 6a,b. Furthermore, a typical river pattern radiating from the fatigue crack initiation (see Figure 6a), the direction of which was consistent with the fatigue crack propagation direction, could be observed in the initial stage of crack propagation. It might be related to the formed fatigue steps resulting from the continuous generation of cleavage planes during fatigue crack propagation. As indicated in Figure $6 \mathrm{c}-\mathrm{f}$, the fatigue fracture characteristics of the PCF and PCPFF specimens were similar. Two adjacent fatigue crack initiation sites existed at/near the edge of specimen. Fatigue cracks initiated at the local corrosion zone, which had an IGC characteristic (see Figure 6d,f). River-like patterns could also be observed but became irregular, which might be attributed to the interaction effect of the propagation process of the fatigue cracks originating from the two adjacent sites. Moreover, as shown in Figure 3b, the depth of IGC was not uniform, which might result in a higher stress concentration and thus accelerate the initiation of fatigue crack under cyclic stresses. As a consequence, the fatigue life of the precorroded 7085-T7452 aluminum alloy specimen exposed to an actual marine atmosphere for three months was reduced by about $93 \%$ compared with that of the as-received specimen.

In addition, as mentioned above, the total fatigue life $\left(N_{\mathrm{f}}\right)$ of the precorroded 7085-T7452 aluminum alloy was increased by selective prefatigue. We presumed that it might be attributed to the following effects. On the one hand, the dislocation density of the precorroded 7085-T7452 aluminum alloy in the marine atmosphere might be increased during the process of prefatigue, which would improve the fatigue strength of the aluminum alloy. On the other hand, the intermittent effect caused by the unloading process following the prefatigue might release the residual stresses in the precorroded 7085-T7452 aluminum alloy specimens, which would delay the initiation of fatigue crack and reduce the fatigue crack growth rate. Moreover, it is worth mentioning that unloading in the process of the fatigue test has a significant influence on the fatigue properties of materials and thus it should not be ignored in the measurement and prediction of fatigue life. 

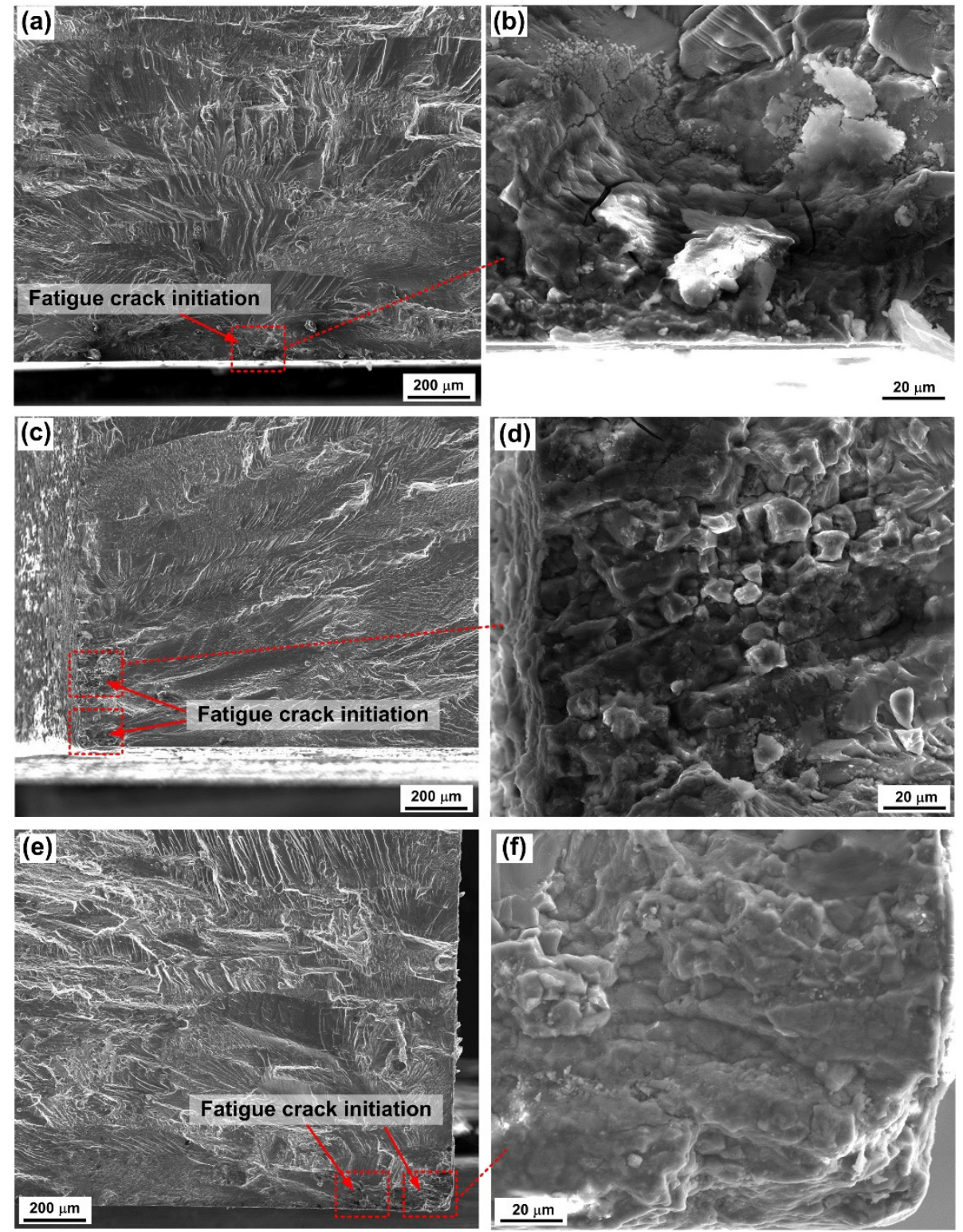

Figure 6. SEM images of the fatigue fractographies of the different 7085-T7452 aluminum alloy specimens: $(\mathbf{a}, \mathbf{b})$ uncorroded fatigue $(\mathrm{UCF}) ;(\mathbf{c}, \mathbf{d})$ precorrosion + fatigue $(\mathrm{PCF}) ;(\mathbf{e}, \mathbf{f})$ precorrosion + prefatigue + fatigue (PCPFF).

\section{Conclusions}

(1) For the 7085-T7452 aluminum alloy exposed for three months in an actual marine atmosphere, both pitting corrosion and IGC were observed. The dominant corrosion mode, IGC, was attributed to the preferential anodic dissolution of GBPs $(\eta)$ which had a lower corrosion potential than that of the aluminum alloy matrix.

(2) Local stress concentration caused by the nonuniform depth of IGC could seriously reduce the initiation period of fatigue crack under cyclic stresses and thus dramatically decreased the fatigue life of the 7085-T7452 aluminum alloy.

(3) Selective prefatigue could improve the fatigue life of the precorroded 7085 aluminum alloy, which might be related to the increase of the dislocation density and the release of residual stresses due to the intermittent effect following the prefatigue. 
Author Contributions: L.S. and L.X. conceived and designed the experiments; L.S. performed the experiments; L.S., L.X., J.T. and J.L. analyzed the data; Q.C. and Y.Z. contributed reagents/materials/analysis tools; L.S. wrote the paper. All authors have read and agreed to the published version of the manuscript.

Funding: The work was supported by the Southwest Institute of Technology and Engineering cooperation fund (grant No. HDHDW5902020105) and the Basic and Advanced Research Project of CQ CSTC (grant No. cstc2018jcyjAX0035).

Institutional Review Board Statement: Not applicable.

Informed Consent Statement: Not applicable.

Data Availability Statement: The data presented in this study are available on request from the corresponding author. The data are not publicly available due to privacy.

Conflicts of Interest: The authors declare no conflict of interest.

\section{References}

1. Zhou, B.; Liu, B.; Zhang, S.G. The advancement of 7xxx series aluminum alloys for aircraft structures: A review. Metals 2021, 11, 718. [CrossRef]

2. Wang, Y.; Cao, L.; Wu, X.; Tong, X.; Liao, B.; Huang, G.; Wang, Z. Effect of retrogression treatments on microstructure, hardness and corrosion behaviors of aluminum alloy 7085. J. Alloys Compd. 2020, 814, 152264. [CrossRef]

3. Xu, W.F.; Wu, X.K.; Ma, J.; Lu, H.J.; Luo, Y.X. Abnormal fracture of 7085 high strength aluminum alloy thick plate joint via friction stir welding. J. Mater. Res. Technol. 2019, 8, 6029-6040. [CrossRef]

4. Liu, S.; Li, Q.; Lin, H.; Sun, L.; Long, T.; Ye, L.; Deng, Y. Effect of quench-induced precipitation on microstructure and mechanical properties of 7085 aluminium alloy. Mater. Des. 2017, 132, 119-128. [CrossRef]

5. Chen, S.Y.; Chen, K.H.; Dong, P.X.; Ye, S.P.; Huang, L.P. Effect of heat treatment on stress corrosion cracking, fracture toughness and strength of 7085 aluminum alloy. Trans. Nonferrous Met. Soc. China 2014, 24, 2320-2325. [CrossRef]

6. Chen, S.Y.; Chen, K.H.; Peng, G.S.; Xin, L.; Chen, X.H. Effect of quenching rate on microstructure and stress corrosion cracking of 7085 aluminum alloy. Trans. Nonferrous Met. Soc. China 2012, 22, 47-52. [CrossRef]

7. Li, C.; Wang, S.; Zhang, D.; Liu, S.; Shan, Z.; Zhang, X. Effect of Zener-Hollomon parameter on quench sensitivity of 7085 aluminum alloy. J. Alloys Compd. 2016, 688, 456-462. [CrossRef]

8. Karabin, M.E.; Barlat, F.; Shuey, R.T. Finite element modeling of plane strain toughness for 7085 aluminum alloy. Metall. Mater. Trans. A 2009, 40, 354-364. [CrossRef]

9. Menzemer, C.C.; Lam, D.F.; Srivatsan, T.S. An investigation of strain concentration in high-strength $\mathrm{Al}-\mathrm{Zn}-\mathrm{Mg}-\mathrm{Cu} \mathrm{Alloy} 7085$ subjected to tensile deformation. J. Mater. Eng. Perform. 2010, 19, 705-713. [CrossRef]

10. Dursun, T.; Soutis, C. Recent developments in advanced aircraft aluminium alloys. Mater. Des. 2014, 56, 862-871. [CrossRef]

11. Prabhu, T. Ram. An overview of high-performance aircraft structural Al alloy-AA7085. Acta Metall. Sin. (Engl. Lett.) 2015, 28, 909-921. [CrossRef]

12. Burns, J.T.; Boselli, J. Effect of plate thickness on the environmental fatigue crack growth behavior of AA7085-T7451. Int. J. Fatigue 2016, 83, 253-268. [CrossRef]

13. Maity, R.; Singh, A.; Paul, S.K. Investigations of fatigue and fracture behavior of AA 7085. J. Mater. Eng. Perform. 2021, 30, 7247-7258. [CrossRef]

14. Dai, P.; Luo, X.; Yang, Y.; Kou, Z.; Huang, B.; Zang, J.; Ru, J. The fracture behavior of 7085-T74 Al alloy ultra-thick plate during high cycle fatigue. Metall. Mater. Trans. A 2020, 51, 3248-3255. [CrossRef]

15. Shuey, R.T.; Barlat, F.; Karabin, M.E.; Chakrabarti, D.J. Experimental and analytical investigations on plane strain toughness for 7085 aluminum alloy. Metall. Mater. Trans. A 2009, 40, 365-376. [CrossRef]

16. Luong, H.; Hill, M.R. The effects of laser peening on high-cycle fatigue in 7085-T7651 aluminum alloy. Mater. Sci. Eng. A 2008, 477, 208-216. [CrossRef]

17. Chen, Y.J.; Liu, C.C.; Zhou, J.; Wang, F.S. Effect of alternate corrosion factors on multiaxial low-cycle fatigue life of 2024-T4 aluminum alloy. J. Alloys Comp. 2019, 772, 1-14. [CrossRef]

18. Song, H.P.; Liu, C.C.; Zhang, H.; Yang, X.D.; Chen, Y.J.; Leen, S.B. Experimental investigation on damage evolution in pre-corroded aluminum alloy 7075-T7651 under fatigue loading. Mater. Sci. Eng. A 2020, 799, 140206. [CrossRef]

19. Joshi, G.; Mall, S. Crack Initiation and growth from pre-corroded pits in aluminum 7075-T6 under laboratory air and salt water environments. J. Mater. Eng. Perform. 2017, 26, 2293-2304. [CrossRef]

20. Genel, K. The effect of pitting on the bending fatigue performance of high-strength aluminum alloy. Scr. Mater. 2007, 57, 297-300. [CrossRef]

21. Chen, Y.J.; Liu, C.C.; Zhou, J.; Wang, X.C. Multiaxial fatigue behaviors of 2024-T4 aluminum alloy under different corrosion conditions. Int. J. Fatigue 2017, 98, 269-278. [CrossRef]

22. Walde, K.V.D.; Hillberry, B.M. Multiple fatigue crack growth in pre-corroded 2024-T3 aluminum. Int. J. Fatigue 2007, 29 , 1269-1281. 
23. Co, N.E.C.; Burns, J.T. Effects of macro-scale corrosion damage feature on fatigue crack initiation and fatigue behavior. Int. J. Fatigue 2017, 103, 234-247. [CrossRef]

24. Zhang, S.; Zhang, T.; He, Y.T.; Du, X.; Ma, B.L.; Zhang, T.Y. Long-term atmospheric pre-corrosion fatigue properties of epoxy primer-coated 7075-T6 aluminum alloy structures. Int. J. Fatigue 2019, 129, 105225. [CrossRef]

25. Zhang, Y.; Pelliccia, D.; Milkereit, B.; Kirby, N.; Starink, M.J.; Rometsch, P.A. Analysis of age hardening precipitates of Al$\mathrm{Zn}-\mathrm{Mg}-\mathrm{Cu}$ alloys in a wide range of quenching rates using small angle X-ray scattering. Mater. Des. 2018, 142, 259-267. [CrossRef]

26. Li, M.H.; Yang, Y.Q.; Feng, Z.Q.; Huang, B.; Luo, X.; Lou, J.H.; Ru, J.G. Precipitation sequence of $\eta$ phase along low-angle grain boundaries in Al-Zn-Mg-Cu alloy during artificial aging. Trans. Nonferrous Met. Soc. China 2014, 24, 2061-2066. [CrossRef]

27. Azarniya, A.; Taheri, A.K.; Taheri, K.K. Recent advances in ageing of 7xxx series aluminum alloys: A physical metallurgy perspective. J. Alloys Compd. 2019, 781, 945-983. [CrossRef]

28. Kairy, S.K.; Turk, S.; Birbilis, N.; Shekhter, A. The role of microstructure and microchemistry on intergranular corrosion of aluminium alloy AA7085-T7452. Corros. Sci. 2018, 143, 414-427. [CrossRef]

29. Yang, X.B.; Liu, J.Z.; Chen, J.H.; Wan, C.Y.; Fang, L.; Liu, P.; Wu, C.L. Relationship between the strengthening effect and the morphology of precipitates in Al-7.4Zn-1.7Mg-2.0Cu alloy. Acta Metall. Sin. (Engl. Lett.) 2014, 27, 1070-1077. [CrossRef]

30. Yang, W.C.; Ji, S.X.; Zhang, Q.; Wang, M.P. Investigation of mechanical and corrosion properties of an Al-Zn-Mg-Cu alloy under various ageing conditions and interface analysis of $\eta^{\prime}$ precipitate. Mater. Des. 2015, 85, 752-761. [CrossRef]

31. Wang, Z. Handbook of Aluminum Alloy and Its Working; Central South University Press: Changsha, China, 2000.

32. Dai, S.G. Environmental Chemistry; Higher Education Press: Beijing, China, 2006. 